\title{
@
}

\section{Do. From Instruction to Agency: Designing of Vocational Orientation Through Artistic Practice}

\author{
Constanze Schmidt
}

Henry, a 16-year-old boy, is standing in the entrance hall of a large Chinese logistics company in the HafenCity in Hamburg. He is playing the recorder. It is lunchtime; employees are pouring out of the elevators to go out for lunch. A few of them turn to glance at Henry. Normally, Henry plays the recorder at small concerts, with his family, or alone, just for relaxation. He even plays it during the breaks of rehearsals when he is stressed. He always carries his recorder with him. At the moment, he is doing a mandatory internship at China Shipping, and had the idea that maybe some of the employees might enjoy hearing him play his instrument. Shortly afterwards, he said, 'Of course, it was embarrassing. But it was a lot of fun too'.

In this particular context, Henry's playing becomes a micro practice, by which he triggers something within a micro framework. Such a sense of

\footnotetext{
I am here.

And as a result, something happens.

C. Schmidt $(\bowtie)$

Graduate Program Performing Citizenship, HafenCity University Hamburg, Hamburg, Germany

(C) The Author(s) 2019

P. Hildebrandt et al. (eds.), Performing Citizenship, Performance Philosophy, https://doi.org/10.1007/978-3-319-97502-3_20
} 
agency, the capacity to act and to prompt an effect, is probably not experienced so often by young people during their internship. In general, interns will focus primarily on adapting to given structures at the workplace and in trying not to attract too much attention. Together with Henry and other ninth-grade teenagers, I have been researching a new form of vocational orientation with artistic practice. In this context, I initiated internships where teenagers performatively explore different places of work. The following questions were decisive for our project:

- How can vocational orientation be combined with an education of agency?

- Ideally, could this take place by introducing an artistic, performative form of agency?

To answer these questions, I will first refer to given theories and research around the notions of work, performance, citizenship and agency, and then describe our specific research setup of a vocational orientation that was informed by artistic practices.

\section{Working Citizen. The Longing for Agency in Current Vocational Orientation}

Concerning professions, the German Basic Law states:

Article 12

(1) All Germans shall have the right freely to choose their occupation or profession, their place of work and their place of training. (Basic Law, p. 3)

Vocational orientation has so far been understood as a life-long process in which an individual can tailor his skills and align his own aspirations with the professional requirements of the outside world. In school-based vocational orientation, the parents, employment agency and school support the young individual's career choice by providing counselling and informing him or her about different vocational fields and corresponding requirements.

Working as a teacher in the German school system at a Hamburg academic high school, I have noticed that many teenagers - in view of the given freedom and an ever-changing world of work-feel overwhelmed 
when it comes to choosing their professional education. ${ }^{1}$ They tend to make short-term decisions, without much reflection, which often have farreaching consequences - such as later breaking off from their studies or education. Students are confronted with two key challenges in the context of their vocational orientation: firstly, their efforts to obtain good grades, in the sense of fulfilling external requirements, do not prepare them for their working life. According to Paul Collard, more than half of the professions that will be socially relevant in the future do not even exist yet. Young people will thus also need to be capable of one thing in the future: to invent careers for themselves (cf. Collard 2013, p. 2).

Additionally, many students have neither been taught nor encouraged how to develop a critical attitude towards our neoliberal working society, and to develop this attitude within their career choices and life planning.

I understand a vocational orientation in which both of these challenges are taken into account as being designed around the idea of a working citizen.

\section{Performing Work}

In post-Fordism, labour is no longer defined as a self-explanatory concept. The same occupation can be perceived by those executing it as either labour or non-labour. For Paolo Virno, the distinction between labour and non-labour has become obsolete, and has been replaced by a politically motivated differentiation between remunerated and non-remunerated life (cf. Virno 2004, p. 117). Thus, it is not solely the occupation itself, but other factors that will determine what is considered as labour.

Companies nowadays expect their employees to optimally organize their work themselves; to not only execute a work-related task, but also to perform it. According to Kai van Eikels, social and communicative skills (negotiating, communicating, presenting), one's personal standing and the corresponding recognition from colleagues, all play a vital role in the assessment of a person's proficiency. What is being assessed is 'their selfenactment - in the double sense of their behaviour and self-presentation as a performing subject in an inter-subjective network of collaboration' (van Eikels 2013b, p. 8, translation by author). A person's occupations are possibly perceived less as work when fulfilled independently within the environment of a company based on teamwork. This also involves the assumption that workers who dedicate themselves to their tasks with their entire personality are less able to distance themselves from their work. 
For work performance in a company, particularly the 'performative sovereignty' (van Eikels 2013 b, p. 4 , translation by author) is attractive. A person can attain performative sovereignty by exposing themselves to situations which they are able to cope with, not through an existing position of power, but only by virtue of their own behaviour in the given situation. Acting, in such a situation, affords the performing person the freedom to shape reality in concrete terms (cf. van Eikels 2013a, p. 32); it never implies merely executing what has been predetermined. Performative sovereignty thus develops only with the actual performance of actions. According to van Eikels, the sovereign here disengages from the political-understood here as institutional authority - and appears as a performative sovereignty in processes of work and collaboration.

Labour - in the context of post-Fordism-in the eyes of Paolo Virno takes on traditional characteristics of political action in the sense of Hannah Arendt, because 'it is in the world of contemporary labour that we find the "being in the presence of others", the "relationship with the presence of others", the beginning of new processes, and the constitutive familiarity with contingency, the unforeseen and the possible' (Virno 2004, p. 51).

Following van Eikels' and Virno's thoughts, citizens thus have the possibility to understand work as a form of political action and to perform it according to their own needs and desires.

\section{The Concept of a Working Citizen}

The concept of a working citizen has been proposed by Ulf Schrader (2013). He suggests that, in view of an exponential economic growth that implies the exploitation of ecological and social resources, work-besides earning a living - should follow the principle of achieving social, ecological and economical fairness. According to Schrader, a working citizen follows a professional self-concept in the course of his working life, in which he 'preferably contributes his labour and time for the benefit of societal objectives relevant to him as a citizen' (Schrader 2013, p. 1, translation by author). ${ }^{2}$ However, Schrader's approach neglects both a broadening of the definition of work and the possibility of a fundamental reorganization of work in our society.

Therefore, concerning vocational orientation and how to design it, I would like to expand the notion of the working citizen through the following ideas ${ }^{3}$ : 
Colin C. Williams criticizes the fact that, in most US top-down models for the promotion of security, esteem and identity, a working citizen is always understood as someone who participates in formal, paid employment. 'In this view, everything is linked to a paid job, including citizenship itself as manifested by the lack of distinction drawn between citizens' rights and workers' rights' (Williams 2007, p. 235). Williams promotes the redefinition and expansion of both grassroots and top-down models of the working citizen to encompass informal work. By extending the 'voluntary and community sectors', integration could be enhanced through informal work and active citizenship. In this context, Williams assesses the programme ACC (Active Citizen Credits) as being inclusive and sensible. The intention of this active citizens' service is to document, present and reward endeavours - such as caring and other work, conducted anywayfor the benefit of their community, for example, by granting tax credits. Individuals would thus voluntarily engage in a self-designed portfolio of work of their choice. 'The result would be the creation of a society founded upon the principle of multi-activity without a radical policy overhaul' (Williams 2007, p. 237).

Impulses towards a fundamental redistribution and reassessment of work in our society are found in the more holistic concepts of 'time prosperity' from the post-growth debate. The proposals made by Friederike Habermann (cf. Habermann 2013, pp. 14-24), and Frigga Haug (cf. Haug 2013, pp. 26-38) and others open up temporal spaces (cf. Konzeptwerk Neue Ökonomie 2013). Their ideas are of interest for the conception of a working citizen, even if they do not explicitly use the term. Here, the citizen takes responsibility for the sustainable organization of paid and unpaid work in our society. Internalized logics of growth are broken up and gainful employment is reduced to one quarter of the former allotted time. The individual will engage in activities, which she/he perceives as meaningful, based on the assumption that people are less interested in optimizing their personal economic situation but instead will use their own, and other, human resources with great care in all areas of life.

The German artist Juliane Stiegele extends post-growth concepts of work organization through the dimension of creativity. The question 'what is humane work?' is examined from different perspectives; for example, with regard to ecological responsibility, economic considerations, social aspects or the need for creativity and culture. In view of ongoing crises and negative impacts on human existence, Stiegele suggests the 
redefinition of all fields of work, involving rethinking and actively shaping them in the sense of creating a social sculpture, similar to the way Joseph Beuys described it in his 'expanded concept of art'. The concept includes the kind of human action aimed at shaping society for the benefit of all (cf. Beuys 1985). Stiegele finds an answer to the question of what humane work could be in artistic practice:

If a person shapes things, works beyond his own interest toward a relation with others and does not lose sight of the overall picture, then he is an artist. $[\ldots]$ This would also serve as a plausible definition of humane work. (Stiegele 2014 , p. 6 , translation by author)

In the light of the concepts outlined above, I understand the working citizen to be an individual who principally acts in a socially, ecologically and economically fair manner and, within these activities, finds and invents their own profession.

\section{The Longing for Agency in Current Vocational Orientation}

For vocational orientation in adolescence, this concept of a working citizen provides various ideas that can be structured according to two interpretations of the term 'orientation': orientating oneself in the sense of determining one's personal standpoint or as an alignment towards a profession. A holistic vocational orientation comprises the development of a differentiated perception of one's own needs, desires and skills-including a form of aesthetic intelligence, and the readiness to allow new perspectives, and to think and act empathically and socially (cf. Collard 2013). The idea of developing and orientating oneself on both personal and social values is based on a comprehensive concept of work, equally including non-paid endeavours like housework, individual work or civic work (cf. Famulla, Butz 2005). Moreover, Ulf Schrader emphasizes the importance of the principle of sustainability. He notes that this topic has, until now, merely played a minor role in the academic study and implementation of vocational orientation in schools (cf. Schrader 2013).

In the light of continual changes in the realm of work, orientation in the sense of 'alignment' refers mainly to aspects like flexibility and adaptation; they have been the subject of controversial discussions in the field of vocational orientation for some time. While Karin Schober considers them 
to be essential (cf. Schober 2001), Marisa Kaufhold suggests that one should indeed develop an inner flexibility, but only acquire such new professional competencies that one personally perceives as meaningful. One should not submit oneself to the pressure of constant adaptation to changes on the job market (cf. Kaufhold, pp. 223-4). Both positions underline self-reliance as a necessary feature.

Within the specific discussion on suitable vocational orientation, a paradigm shift-from professional guidance towards the promotion and support of an individual planning ability and capacity to act-has already taken place. Currently, for practical implementation, this implies that young people are only offered impulses that will motivate them to shape their own educational, professional and life planning (cf. Butz 2008).

In my view, the very experience of difference gained through artistic processes, as Ulrike Hentschel describes (cf. Eckert, Hentschel 2015), offers a chance to break with habitual modes of perception in the working world. Following Martin Seel (1993), for Hentschel, the peculiarity of art is "to point to "the world". The art can only do this by distinguishing itself from "the world", thereby enabling the experience of difference or distance' (cf. Eckert, Hentschel 2015, p. 3, translation by author). Thus, artistic performative strategies may evade exploitation on the economic level.

From this, I conclude that what is called for to achieve a vocational orientation towards a working citizen is a performative, artistic form of agency.

\section{Agency}

Based on Cornelia Helfferich's compilation of various social-scientific concepts of agency (cf. Helfferich 2012, pp. 9-39), agency can be understood like this: agency describes a person's conscious capacity to act and be effective, which they themselves perceive as meaningful and creative. A possibility to act depends on social factors. It determines the preconditions for and/or a consequence of agency. A subjective experience of agency does not necessarily coincide with factual circumstances.

Michel De Certeau sees routine practices as presenting an opportunity for creative practices of appropriation-individuals decisively integrate predefined structures into their everyday life in a joyful process of resignification. To him, 'walking in the city' exemplifies the process of active consumption of a place- a city has a system of streets; its inhabitants, however, take shortcuts that best suit their purposes. Thereby, they create 
new paths, and thus impact the prevailing system. De Certeau ascribes an element of creative resistance to such tactical practices, whereby an individual would not be aiming at revolution, but rather, simply evading the control efforts deployed by the 'disciplining forces' (cf. de Certeau 1988).

With de Certeau, the term 'agency' thus becomes a description of creative processes of appropriation. Agency signifies the capacity to consciously individualize, influence and re-signify prevailing structures.

\section{How Artistic Instructions May Lead to Agency: The Project InTERNSHIP REPORT}

The project 'Internship Report'4 was conceived as follows: in January 2016, ninth-grade students at the Europaschule Gymnasium Hamm in Hamburg undertook the usual three-week internships in different companies in order to gain their first work experience-for example, at a bank, a dental practice or a Chinese shipping company. During the preparation of our vocational orientation project, 22 teenagers and I worked with various artistic practices. In this context, we discovered that an artistic, performative form of agency could be developed and supported by means of particular art-based instructions. Usually, the tasks related to an internship are aimed at helping teenagers find out for themselves whether they are suited for a particular job and the given structures at that workplace-or not. The instructions of the 'internship through artistic practice' served as a research tool, aimed at testing the work environment and designing one's own internship. A series of questions were formulated to guide the process:

- What does the working environment need?

- In carrying out their work, what kind of experiences do the teenagers see as also pleasing their colleagues?

- How would they like to design their own work?

- What kind of new professions do they invent for themselves?

Based on these questions, the students developed specific artistic interventions within the workplace-using sounds, images, actions or movements-and then documented the reactions of their colleagues.

In the weeks before their internship, the young people had tried out different artistic tasks in businesses throughout the neighbourhood. The special form of instructions had emerged because these teenagers seemed to enjoy carrying out tasks in general. The students also seemed accustomed 
to receiving clear instructions, as they were used to transparent rules and their rigorous implementation from school ('the strictest school in Germany' cf. Gall 2012). In my role as artist, and by working with artbased instructions, I could give them 'license to do things differently'. The project was aimed at providing the students with small spaces, where they, for once, would be allowed to bypass the rules set by their environment. This also enabled them to withdraw from the neoliberal logics of adaptability, usability and achievement orientation, which are found in economy as in common educational contexts. Instruction-based education is turned inside out by instruction-based art.

\section{Instruction-Based Art: Permission and Scope for Action}

On August 29, 1952, the pianist David Tudor sits down at the grand piano, starts the stopwatch and closes the piano. In the four minutes and thirty-three seconds that follow one cannot hear any piano music, only an occasional coughing from the audience, the shuffling of feet and someone sneezing. The repeated opening and closing of the piano lid marks all three movements of this premiere of the composition, whose score was defined as follows:

\begin{tabular}{c}
\hline I \\
Tacet \\
II \\
Tacet \\
III \\
Tacet \\
\hline
\end{tabular}

By measuring the time, and the opening and closing of the piano lid, John Cage's composition 4'33" (Cage 1960) creates a framework that directs the audience's attention to incidental sounds occurring in the music hall. The recipient is thus referred to his own expectations of a concert. By reinterpreting the sounds all around them as music, the audience may become aware of their own participation in the concert. Cage upgrades such ordinary sounds as essential elements of our world. He reflects the function and the material of art through art itself (cf. LaBelle 2002, p. 48).

Cage's conceptual compositions had a decisive influence on the Fluxus movement of the 1960s. In Fluxus, I found the same features and effects of instructions manifested that became relevant for our project Internship 
Report. With the introduction of scores, according to Ken Friedmann, a 'core principle of musicality' was transferred to Fluxus art (cf. Friedmann 2002). Whilst in the field of music, the 'musical score' represents a script for music notation, the 'event score' in Fluxus describes already performed or yet to be realized actions. Like in Cage's composition $4^{\prime} 33^{\prime \prime}$, such actions develop on the basis of everyday activities, which anyone could perform. As the event score used in Fluxus addresses, in linguistic form, the original artist themselves, the performer and/or the audience, it becomes an instruction understandable for all.

The 'core principle of musicality' of instruction-based art is not focused on an original work, but rather, on the specific realization of an event score by different individuals with the participation of varying audiences in different contexts and at different times. In Yoko Ono's work Cut Piece (1964), performed on various occasions by herself and other artists, people in the audience were instructed to cut off pieces of the performer's clothing with an available pair of scissors.

\section{roko Ono, Cut Piece}

First version for single performer:

Performer sits on stage with pair of scissors placed in front of him.

It is announced that members of the audience may come on stage - one at a time - to cut a small piece of the performer's clothing to take with them.

Performer remains motionless throughout the piece.

Piece ends at the performer's option. ${ }^{5}$

By conceiving her work as a score, Yoko Ono enabled the transformation of one idea into multiple different experiences. Ono herself once characterized her performance of 1964 as a spiritual act, as a genuine contribution, an experience of giving the audience what it wishes to take. The male performer Jon Hendricks, who performed the score in front of and with his new students of the Douglas College in New York, experienced a transition in the relationships of authority. During some other performances of Cut Piece, the audience displayed particularly sexually aggressive behaviour (cf. Concannon 2008, pp. 83, 85). As the author of the instruction, Yoko Ono becomes a kind of 'facilitator', who provides the active recipient with specific actions and experiences (cf. Umathum 2004). This, and other event scores, departed from the physical space of art venues; Ono made the scores publicly accessible in her book Grapefruit (Ono 2000). ${ }^{6}$ 
Artistic instructions question the conventional concept of the author and recipient. In Cage's $4^{\prime} 33^{\prime \prime}$, the audience's participation is rendered visible through the given specific framework. In instruction-based art, as in Yoko Ono's Cut Piece, control over the work is partially surrendered by the author by delegating the realization of the artistic work explicitly to the recipient. The instruction is completed only through the performance of the recipients; their participation and artistic decision-making become indispensable. For Ken Friedmann, the proposition of participation defined in the scores corresponded with Joseph Beuys' democratic concept of 'Everyone is an artist' (cf. Friedmann 2002, p. 126). In the sense of an extended definition of art, Beuys understood every human being as being capable of creatively shaping society (cf. Beuys 1985).

Through the instruction to act, the recipient receives permission. As Mary Patterson says about Playing Up, a Live Art Game by Sibylle Peters, performed at the Tate Modern in 2016: 'The rules of this game are simply to follow the rules, which are less like rules and more like permissions' (Paterson 2016, p. 1). In the instructions of this Live Art Game it is stated, 'that to commit to a task can set you free' (Peters 2016, p. 6).

Similar experiences, from a special form of instruction-the selfcommitment-were made by contemporary artist Sophie Calle:

I like being in control and I like losing control. Obedience to a ritual is a way of making rules and then letting yourself go along with them [...] I'm always dreaming of situations where I won't have to decide anything. Where I can really let myself go. (Calle, in an interview with Christine Macel. (Macel 2003 p. 75))

The method of the artistic instruction produces the liberating effect (cf. Umathum and Rentsch 2006, pp. 9-10) that the composer Igor Strawinsky describes as a special essence of an artistic attitude and work:

My freedom consists in acting within the tight framework that I have set for myself for each of my projects. [...] Whoever deprives me of my restraint, also strips me of my force.

The more compulsion you impose, the more you are freed from the chains that bind the spirit. (Strawinsky 1949, p. 46)

An artistic instruction gives permission and provides new space for actions and experiences. This new space is designed by the performing person, who creates their own set of rules. 
Even by refusing the scope for action, the recipient performs an attitude. I would infer that the appropriation of an instruction may lead to independent, self-reliant action-to agency.

\section{Opening Up Scope for Action Within Institutions}

The scope for action-the new space-created with the help of instructions, always develops within an existing space that, according to de Certeau, has in turn constituted itself through activities and agreements. ${ }^{7}$ During an internship, these spaces and the supervisory bodies of workplace and of school overlap for three weeks. In this situation, it is not quite clear which rules actually apply. One may have to break one rule in order to follow another. This is where, in the guise of school assignments, our artistic instructions come in. The instructions allow for a new space, which can be designed according to one's own rules. Such scope for action is normally not foreseen within institutions. Neither employers or schools, nor even authors of such instructions, have complete access to this space. The prevailing rules of workplace and school thus become unstable.

This process opens up new perspectives onto institutional rules, creating potential for their appropriation. The scope for action here provides a form of freedom, as defined by de Certeau-by adopting the instructions for themselves, in using their own approach, the students temporarily allow a new space to emerge in the frame of their internship. They perform a new space.

Through the medium of their bodies, boundaries between art and everyday life are dissolved. Action remains action. Through the artistic, daily and political dimension of action, routine activities at school and the workplace are affected. By experiencing new scope for action, an intern has the possibility of attaining a new self-understanding. Thus, there is potential space for agency.

\section{The Licence for 'Doing Things Differently'}

\section{Two Different Kinds of Artistic Instructions}

For the students' internship, I devised a set of instructions in their research journals, which they then could use as blank permissions. How would the teenagers deal with this new scope? What would they wish for at their working environment that normally was not considered as belonging 
there? Or-in the sense of Cage's composition — which coughing, which shuffling of the feet would they choose to make heard?

Generally speaking, there were two different kinds of instructions involved:

\section{Testing the Working Environment-Instructions with a Predetermined Micro Practice}

The interns carried out a number of activities in order to test reactions in their working environment. In this phase, the content of the instructions was based on concepts for a post-growth society, including concepts of time prosperity. Besides this, they were based on practices that the students had previously used as forms of micro resistance at school against achievement orientation, for example, 'talking to their classmates' or 'snoozing at their desk'. These sensorial physical practices were examined with regard to their reflexive, subversive and experimental potential, and then exaggerated in the form of instructions in the work context. Following Elke Bippus' definition, I refer to them as micro practices (cf. Bippus 2015, pp. 216-21). Initially, a constitutive element for micro practices, according to Bippus, is their pharmacological dimension-as both formative and deformative practice simultaneously (cf. Mikropraktiken). However, regarding this research project, I would expand her concept to include individual practices which, when transferred to a new context, have an interventionist effect. To break the rules was therefore set up as a new rule and the students were empowered to follow it.

For their internship, some students had in their research journal the instruction to:

Take two additional breaks, during which you sleep at the workplace for three minutes.

Pauline, a student, did her internship at a bank. The manager of the bank took a keen interest in the tasks Pauline found in her research journal. He suggested a solution for following the instruction: not to sleep at the counter or in the customer area, but in the back office of the bank. This would provide the opportunity to 'make everything ok, afterwards'. In this case, the creative enactment of a predetermined micro practice within prevailing structures was at stake, and the straightforward character of the instruction indeed had a productive effect. It gave Pauline permission to break with, or at least question, rules at the workplace by referring 
to the licence of an 'artistic research task', in the face of-or even together with-her superior, the bank manager. The result of this testing of the working environment was that the bank manager used the newly created intellectual leeway actually as an opportunity for reflection. In an interview with both Pauline and me, he talked about what it meant to take your breaks with self-responsibility or to 'test the limits'.

\section{Shaping the Working Environment: Instructions with Self- Created Activities}

The other form of instruction given to the students was more open, and implied self-determination-implementing their own ideas and taking their own decisions. An example of such an instruction might be:

Perform an activity at the workplace that you enjoy doing and that also pleases your colleagues.

A girl named Bintou had undertaken a boring internship in a dental practice. The atmosphere there was marked by mutual disinterest. She had hardly any tasks to do and she stood around a lot. At this time, many refugees were coming to the dental practice. Bintou is a native English speaker. After just a few days, she had invented the job of interpreter for herself in dental practices.

Perhaps she would have engaged in this activity even without the instruction. By fulfilling her research tasks, however, she consciously experienced her scope for action and could appreciate her activity as meaningful. After this, she gave herself permission to no longer follow any instructions from the research journal.

Another performance of this instruction was enacted by Henry, mentioned earlier, by playing his flute in the entrance hall of the Chinese shipping company. After the internship, we jointly reflected the students' experience, based on an artistic presentation titled Internship Report ('Praktikumsbericht'). In making the presentation, Henry took advantage of his newly found scope for action by making himself heard on a Wagner tuba (Fig. 1).

Agency became visible in the students' meaningful and creative appropriations of pre-existing structures. The corresponding instructions provided them with a space they could design for themselves by developing their own set of rules within the rules of their chosen workplace. In this sense, 'To commit to a task can set you free' meant empowering them to 


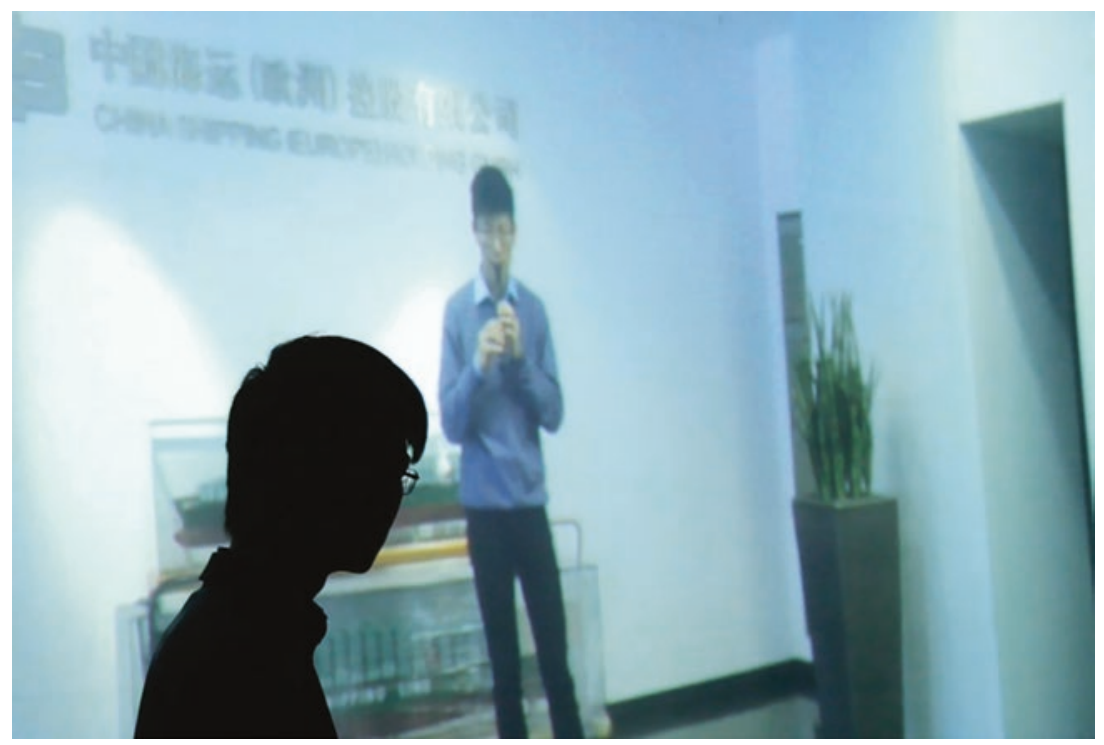

Fig. 1 During the presentation, Henry watches footage of himself playing the recorder in the China Shipping company (Hamburg, 2016)

contribute something of their own to the workplace-independent from the requirements of the workplace - and so shape the environment for themselves and others. The instructions required reflection upon oneself and on existing structures - the act of translation and the playing of a recorder counted, amongst the young people, as answering human need that was found in their working environment. They thus performed their self-understanding as interns within an institution and manifested their identity as young working citizens.

The instructions, and their performance by the students, can be seen as an experimental embodiment of the above-mentioned Article 12 of the Basic German Law regarding the freedom to choose one's occupation; an article, in this light, that can itself be interpreted not only as a right but as an instruction that might be embodied individually in an ever-changing world of work: Choose your vocation freely. Design your vocation. Invent your vocation. As working citizen.

The project Internship Report opens up the possibility to experience one's own present or future workplace as being malleable through action; thereby reinterpreting, redefining and appropriating both this space and 
one's occupation in a positive sense. In his composition 4'33", Cage was able to provide a framework capable of directing the audience's attention to incidental sounds during a concert; sounds which usually are considered disturbing. He distinguishes the ordinary noises of the audience-the coughing, the shuffling of feet, the snoozing-by redefining them as independent sounds. Based on its instructions, the project Internship Report provides a comparable framework aimed at directing one's focus, within the scope of one's activities, more towards recognizing individual human needs that, in the context of neoliberal working relations, are normally neglected-such as sleeping, language translating and playing the recorder. If this concept were transferred to the level of social responsibility and designing of working practices, which opportunities would it signify for the future of work and the citizens' participation within the process?

By providing space for agency in Article 12 of the Basic Law, responsibility is returned to each individual in two key respects: the responsibility to respect and honour one's own wishes, values and abilities and the responsibility to perform one's own activities as civic action. This raises the question for every subject, according to which values one intends to shape the space:

Through which practices would a person like to become a working citizen?

This is the chance for citizenship to be reconsidered and negotiated from the perspective of an active subject being an inclusive phenomenon.

\section{Notes}

1. Also, Heinz Dedering writes about the overwhelming situation for young people (cf. Dedering 2002, pp. 25-6).

2. Schrader's definition of citizenship is oriented on the tradition of the republican understanding of citizenship, by which a good citizen actively contributes to common welfare and voluntarily fulfils duties.

3. In Germany, the concept of the working citizen is currently of particular relevance in view of its integrative qualities. Until 2014, it could take several years before persons seeking asylum, or with a 'tolerated' status of residence, was granted a work permit. Considering that, especially since the summer of 2015, an increasing number of people sought refuge in Germany, the policymakers and economists have made an effort to facilitate entry to the job market. Reasons for this are the costs of social benefits that otherwise would be due, a shortage of skilled workers in Germany and, not least, 
the prospects successful 'professional integration', as $70 \%$ of the refugees are under 30. Here, the law of integration of August 6, 2016 plays a vital role (Cf. Pro Asyl 2017).

4. The project was conducted at the Europaschule Gymnasium Hamm in Hamburg, from November 2015 to May 2016. Concept and research: Constanze Schmidt; artistic assistance: Teresa Rosenkrantz; educational assistance: Ulrike Mack.

5. Yoko Ono's Cut Piece, quoted after Concannon, p. 82.

6. From my point of view, an interesting approach to enabling the artistic scores to enter the recipients' everyday life is George Brecht's idea of distributing artistic scores via newspapers and postcards (cf. Dezeuze 2002, p. 79).

7. De Certeau distinguishes between space and place. A place is the structure of relationships between elements. Two items can never be at the same place. A place signifies clarity and stability. The space develops from changeable elements- like direction, speed and time - as a 'polyvalent unity of conflictual programs and contractual proximities' (de Certeau 1988, p. 117).

\section{REFERENCES}

Basic Law for the Federal Republic of Germany. 2012. Article 12 (Occupational Freedom). https://www.gesetze-im-internet.de/englisch_gg/englisch_gg.pdf. Accessed 9 Mar 2018.

Beuys, J. 1985. Sprechen über Deutschland: Rede vom 20. November 1985 in den Münchner Kammerspielen. In Reden über das eigene Land: Deutschland, ed. H. Mayer, J. Beuys, M. Mitscherlich-Nielsen, and A. Schönherr. Bertelsmann: Munich.

Bippus, E. 2015. Adrian Pipers Funk Lessons. Eine Mikropraxis transformierender Affirmation. In Kunst und Wirklichkeit heute: Affirmation - Kritik Transformation, ed. L. Everts et al. Bielefeld: transcript.

bridge - Das Berliner Netzwerk zur Unterstützung von Bleibeberechtigten und Flüchtlingen auf dem Weg ins Unternehmen. www.aub-berlin.de/fuer-erwachsene/bridge/. Accessed 9 Mar 2017.

Butz, B. 2008. Grundlegende Qualitätsmerkmale einer ganzheitlichen Berufsorientierung. In Berufsorientierung als Prozess - Persönlichkeit fördern, Schule entwickeln, Übergänge sichern. Ergebnisse aus dem Programm 'Schule -.Wirtschaft/Arbeitsleben', ed. G.-E. Famulla. Baltmannsweiler: Schneider Hohengehren.

Cage, J. 1960. 4'33: For Any Instrument or Combination of Instruments. New York: Peters.

Collard, P. 2013. Vortrag auf der Tagung der Kultusministerkonferenz und der Stiftung Mercator im März 2013 quoted after Grundsatzpapier zur Kulturellen Bildung in den Kulturräumen des Freistaates Sachsen Vogtland-Zwickau, 
Leipziger Raum, Erzgebirge-Mittelsachsen, Niederschlesien-Oberlausitz, Chemnitz, Leipzig und Dresden, p. 2. www.dresden.de/media/pdf/kulturamt/ Grundatzpapier_KuBi_Kulturraeume_Sachsen.pdf. Accessed 3 Mar 2018.

Concannon, Kevin. 2008. Yoko Ono's Cut Piece: From Text to Performance and Back Again. PAJ: A Journal of Performance and Art 30 (3 (MIT Press)): 81-93.

de Certeau, M. 1988. The Practice of Everyday Life. Berkeley/Los Angeles/ London: University of California Press.

Dedering, H. 2002. Entwicklung der schulischen Berufsorientierung in der Bundesrepublik. Deutschland. In Berufsorientierung in der Schule. Grundlagen und Praxisbeispiele, ed. J. Schudy. Bad Heilbrunn/Obb.: Klinkhardt.

Dezeuze, A. 2002. Origins of the Fluxus Score. On Fluxus. Performance Research 7 (3): 78-94.

Eckert, C., and Hentschel, U. 2015. 'Constanze Eckert im Gespräch mit Ulrike Hentschel. Über mögliche Zusammenhänge von Kunst (Theater) und Bildung’ in Mission Kulturagenten - Onlinepublikation des Modellprogramms "Kulturagenten für kreative Schulen 2011-2015. http://publikation.kulturagenten-programm.de/detailansicht.html?document=160. Accessed 3 Mar 2018.

Famulla, G.-F., and Butz, B. 2005. Schule - Wirtschaft/Arbeitsleben -Glossar:Berufsorientierung. http://www.swa-programm.de/texte_material/ glossar/index_html_stichwort=Berufsorientierung.html. Accessed 9 Mar 2017.

Friedman, K. 2002. Working with Event Scores: A Personal History. On Fluxus. Performance Research 7 (3): 124-128.

Gall, I. 2012. Hamburgs strengste Schule setzt glasklare Regeln. https://www.welt. $\mathrm{de} / \mathrm{regionales} / \mathrm{hamburg} /$ article 112176008 /Hamburgs-strengste-Schulesetzt-glasklare-Regeln.html. Accessed 6 Jan 2017.

GGUA Flüchtlingshilfe e. V. Arbeitserlaubnis mit Duldung. http://www.einwanderer.net/uebersichten-und-arbeitshilfen/. Accessed 9 Mar 2017.

Habermann, F. 2013. Die Freiheit, so zu leben, wie wir es wollen. In Zeitwohlstand. Wie wir anders arbeiten, nachbaltig wirtschaften und besser leben, ed. Konzeptwerk Neue Ökonomie. Munich: oekom Verlag.

Haug, F. 2013. Zeit, Wohlstand und Arbeit neu definieren. In Zeitwohlstand. Wie wir anders arbeiten, nachbaltig wirtschaften und besser leben, ed. Konzeptwerk Neue Ökonomie. Munich: oekom Verlag.

Hellferich, C. 2012. Einleitung. Von roten Heringen, Gräben und Brücken. Versuche einer Kartierung von Agency-Konzepten. In Agency. Die Analyse von Handlungsfähigkeit und Handlungsmacht in qualitativer Sozialforschung und Gesellschaftstheorie, ed. S. Bethmann et al. Weinheim/Basel: Beltz Juventa Verlag.

Kaufhold, M. 2009. Berufsbiografische Gestaltungskompetenz. In Eigen-Sinn und Widerstand. Bildung und Arbeit, ed. A. Bolder and R. Dobischat. Wiesbaden: VS Verlag für Sozialwissenschaften. 
Konzeptwerk Neue Ökonomie. 2013. Zeitwohlstand. Wie wir anders arbeiten, nachbaltig wirtschaften und besser leben, ed. Konzeptwerk Neue Ökonomie. Munich: oekom Verlag.

LaBelle, B. 2002. Reading Between the Lines: Word as Conceptual Project. On Fluxus. Performance Research 7 (3): 47-53.

Macel, Christine, ed. 2003 Sophie Calle, M'as-tu vue. Exhibition catalogue. Munich/Berlin/London: Prestel.

Mikropraktiken: Formen des Widerstandes und Engagements. https://mediaandparticipation.com/ueber/teilprojekt-5/. Accessed 12 Mar 2017.

Ono, Y. 2000. Grapefruit: A Book of Instructions and Drawings. New York: Simon \& Schuster.

Paterson, M. 2016. Playing Up London: Live Art Development Agency. http:// playingup.thisisliveart.co.uk/playing-up-by-mary-paterson/. Accessed 9 Mar 2017.

Peters, S. 2016. Instructions. In Playing Up! A Live Art Game for Kids and Adults, ed. S. Peters. London: Live Art Development Agency.

Pro Asyl. 2017. Integrationsgesetz in Kraft: Die Neuerungen im Überblick. https://www.proasyl.de/news/integrationsgesetz-in-kraft-die-neuerungenim-ueberblick/. Accessed 9 Mar 2017.

Schober, K. 2001. Berufsorientierung im Wandel - Vorbereitung auf eine veränderte Arbeitswelt. http://www.swa-programm.de/tagungen/bielefeld.html. Accessed 9 Mar 2017.

Schrader, U. 2013. Nur noch kurz die Welt retten? Konsequenzen der Diskussion um eine nachbaltige Entwicklung für die Berufsorientierung. http://www.bwpat. $\mathrm{de} / \mathrm{ht} 2013 / \mathrm{ft} 02 / \mathrm{schrader}$ ft 02 -ht2013.pdf. Accessed 3 Mar 2018.

Seel, M. 1993. Intensivierung und Distanzierung. Kunst und Unterricht 176: $48-49$.

Stiegele, J. 2014. UTOPIA TOOLBOX. Eine Anstiftung zur radikalen Kreativität. Kunst als Antrieb einer zukunftstauglichen Ökonomie. http://www.postwachstumsoekonomie.de/wp-content/uploads/2014-11-12_Stiegle-UtopiaToolbox.pdf. Accessed 27 Feb 2018.

Strawinsky, I. 1949. Musikalische Poetik. Mainz: Schott.

Umathum, S. 2004. Do It Yourself! In Kunst der Aufführung. Aufführung der Kunst, ed. E. Fischer-Lichte, C. Risi, and J. Roselt. Berlin: Theater der Zeit, Recherchen 18.

Umathum, S., and Rentsch, S. 2006. 'Vom Gehorchen. Über das Verhältnis von HandlungsanweisungenundästhetischerErfahrung' inSonderforschungsbereich 626 (ed.) Ästhetische Erfahrung: Gegenstände, Konzepte, Geschichtlichkeit. http://www.sfb626.de/veroeffentlichungen/online/aesth_erfahrung/aufsaetze/umath_rentsch.pdf. Accessed 3 Mar 2018.

van Eikels, K. 2013a. Die Kunst des Kollektiven. Performance zwischen Theater, Politik und Sozialökonomie. Munich: Wilhelm Fink Verlag. 
2013b. Was uns deine Spontaneität wert ist: Improvisieren zwischen Kunst und Ökonomie. https://kunstdeskollektiven.wordpress.com/2013/06/29/ was-uns-deine-spontaneita\%CC\%88t-wert-ist-improvisieren-zwischen-kunstund-okonomie. Accessed 9 Mar 2017.

Virno, P. 2004. A Grammar of the Multitude. Los Angeles/New York: Semiotext(e).

Williams, C.C. 2007. Rethinking the Future of Work. Directions and Visions. Basingstoke/New York: Palgrave Macmillan.

Open Access This chapter is licensed under the terms of the Creative Commons Attribution 4.0 International License (http://creativecommons.org/licenses/ by $/ 4.0 /$ ), which permits use, sharing, adaptation, distribution and reproduction in any medium or format, as long as you give appropriate credit to the original author(s) and the source, provide a link to the Creative Commons licence and indicate if changes were made.

The images or other third party material in this chapter are included in the chapter's Creative Commons licence, unless indicated otherwise in a credit line to the material. If material is not included in the chapter's Creative Commons licence and your intended use is not permitted by statutory regulation or exceeds the permitted use, you will need to obtain permission directly from the copyright holder.

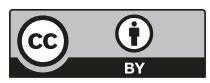

